\title{
Effect of Leadership Style on the Delivery of Quality Education in Public Technical and Vocational Education Institutions in Kenya
}

\author{
Sawega James Walala ${ }^{1}$, Esther Wangithi Waiganjo ${ }^{1} \&$ Agnes Njeru ${ }^{1}$ \\ ${ }^{1}$ College of Human Resource Development, Jomo Kenyatta University of Agriculture \& Technology, Nairobi, Kenya \\ Correspondence: Sawega James Walala, Business Administration, College of Human Resource Development, Jomo \\ Kenyatta University of Agriculture \& Technology, Nairobi, Kenya. E-mail: kaleksawega@gmail.com
}

Received: January 11, 2015

Accepted: January 16, 2015

Online Published: January 16, 2015

doi:10.5430/ijba.v6n1p63

URL: http://dx.doi.org/10.5430/ijba.v6n1p63

\begin{abstract}
The purpose of the study was to investigate the effect of leadership style on the delivery of quality education in public technical and vocational education institutions in Kenya. The study adopted Survey research design while target population was 689 employees in the Ministry of Educations' Directorate of Technical Education, National Polytechnics and Technical Institutions. Simple random, stratified and purposive 1 sampling techniques were used to select 11 managers in Directorate of Technical Education, 15 administrators from National Polytechnics and other technical institutions, and 220 instructors from technical institutions. Data was collected using structured questionnaires and interview schedules. Data was analyzed both quantitatively and qualitatively using the statistical package for social science (SPSS) version 17.0. Descriptive and inferential statistics and content and analyses were used for specific data. Regression analysis was done to determine the relationship between the dependent and the independent variables. The analysis was further amplified by subjecting selected results to graphical and tabular techniques. The study established that the leadership style influenced the success of the reforms process in the organizations as the process became more successful where the management involved other staff in the process but took the leadership role which will in turn enhanced the quality of the technical education. The study also established that the leadership style directly influenced the quality of education to a large extent. The study recommended that the management of the technical educational institutions should adopt leadership styles which could accommodate the views of every staff and involved everyone in the process but the management should show that way of reforms or change.
\end{abstract}

Keywords: delivery, leadership style, quality education

\section{Introduction}

Adaptation to change has become a common agenda for organizations of all types including health care, business, social, governmental, educational, and cultural. The later decades of the twentieth century will go down in history as an era of perpetual change. As such change has been an integral part of human development with knowledge and education at its core (Kennedy \& Lee, 2008). Knowledge and curiosity have brought enormous change in the human situation and its physical and socio-economic environment. This is due to the increased values placed on education as a vital tool for development. According to Ojiambo (2009), education development would lead to accelerated economic growth, more wealth and income distribution, greater quality of opportunity, availability of skilled manpower, decline in population growth, long life, better health outcomes, low crimes rate ,national unity and political stability.

Since education systems the world over are responsible for knowledge generation and transfer in society, the struggle to regulate the cyclic and complex association between change and knowledge has been underway at different levels of the reforms with varying degrees of implementation success (Haris, 2009; Levin, 2009). The motives behind these regulations have always been pristine, especially in the presence of political expediency (Gunter, 2008; Hargeaves, 2005; Harris, 2011; Levin and Fullan, 2008; Levin, 2010), market ruthlessness (Cheng, 2010; Hargreaves and Shirley, 2009; Hill, 2009) and even religious predispositions in some education systems (Kennedy \& Lee, 2008).

According to a study by Margherita (2006), educational reforms in fourteen European countries (viz Denmark, Finland, France, Germany, Italy, Ireland, Netherlands, Portugal, Sweden, United Kingdom) were intended to make more youth attend colleges. The study found that these policy changes resulted in one additional year in school in 
some countries while in others it resulted in up to three additional years of schooling. In the United States of America (U.S.A), the reforms were aimed at producing graduates who will be competitive in the global market arena (Berube, 2004).

In Africa educational reforms were done for various reasons and with mixed levels of success. In South Africa the post-apartheid educational reforms were geared towards achieving equality because the government inherited one of the most unequal societies in the world (Bhikha, 2002). The reforms focused on three interventions namely: education finance reform, curriculum reform and teacher rationalization process (Bhikha, 2002). According to Jansen and Taylor (2003), the reforms achieved only little success due to what he terms as lack of wide systematic thinking, uncoordinated nature of the initiatives and the conflicting logic of the different initiatives. In Benin educational reforms were not implemented due to lack of budgetary support after United States Agency for International Development (USAID) withdrew its support and the national government was unable to finance the reforms alone (Bhikha, 2002). In Uganda, national politics often superseded educational reform goals and the local communities frequently received mixed signals regarding their involvement in their children's education (Moulton et al., 2002).

Educational change in Kenya dates back to the early years of post independent Kenya. After independence, the government appointed a committee of eminent Kenyans chaired by Prof. Ominde in 1964 and Gachukia, (2003) to collect views from the people and reform the education sector to be more responsive to the needs of independent Kenya. They recommended a system that will foster national unity; create human resources and development (Sessional Paper no. 1 2005).

The implementation of these reforms has however not achieved the desired outcome. Various factors have been found to influence the change process in organizations (Ochugudu and Ayatse, 2013). One of the factors found to influence the change process in the organizations is the leadership style. Leaders are usually saddled with the responsibilities of achieving the goals and objectives of the organization but the extent to which they can achieve these goals depend on the style of leadership adopted in line with the dynamics of the time. Strong leadership is the backbone of an organization. Leaders create the vision, support the strategies, and are the catalyst for developing the individual bench strength to move the organization forward. Yet leadership can be an elusive characteristic, and developing leaders to their full potential remains one of the greatest challenges for organizations today. This makes leadership question a serious issue for both researchers and managers alike. This study sought to determine whether the leadership style in the technical training institutions have influenced the quality of education through the change management.

The word 'leadership' has been used in various aspects of human endeavour such as politics, businesses, academics, social works, etc. with each of the environment having it own peculiarities and requiring different leadership style. Thus, the degree to which an individual exhibits leadership traits and succeed depends not only on his characteristics and personal abilities, but also on the characteristics of the situation and environment in which he finds himself. Leadership style in an organization is one of the factors that play significant role in enhancing or retarding the interest and commitment of the individuals in the organization. It is the manner and approach of providing direction, motivating people and achieving objectives. Thus, Glantz (2002) emphasizes the need for a manager to find his leadership style.

Often, the style of leadership adopted by a leader to drive the organization towards its goal can be influence by his or her background, personal experience, inclination, ideology, culture and even orientation without necessarily being based on the dynamics of the situation. This, to a large extent has been the major factor for leadership failure. The import of leadership and organizational effectiveness is the fact that, if the leader succeeds as a result of the style adopted, the organization also succeeds and if he or she fails the organization also fails. It was therefore important to investigate the influence of the leadership style on the effectiveness of the technical training institutions.

The role of technical educational institutions in Kenya is furnishing skills required to improve productivity, raise income levels and improve access to employment opportunities (Nyerere, 2009). However, the levels of unemployment in the country have been souring every year. This has resulted to the reforms in the sectors such as the Technical, Industrial, Vocational and Entrepreneurship Training (TIVET) Bill 2012 which among others aimed at making the sector shift from time bound curriculum-based training to flexible and competency-based training, from supply-led training to demand-driven training, expansion of the technical institutions to provide training to large numbers of young people who graduate annually from secondary and primary school systems and to harmonize the education training system for East African Countries (Owate, 2012). 


\subsection{Statement of the Problem}

Numerous reforms in the technical educational training institutions in Kenya have been launched with the view of addressing such challenges as relevance, educated unemployed, more demand for change in education to fit the industry, infrastructural inequities and dilapidated facilities and shortage of technical teachers (Chang'ach, 2013; Otiato, 2009). The number of students being absorbed in the technical institutions also has been found to be below the threshold (Harris, 2011). For instance, TIVET Act (2012) recommended streamlining curriculum to industrial needs, face-lifting physical facilities and expanding the institutions to accommodate more students. In line with the Act is the Vision 2030 through which Kenya expects to become a newly industrialised, middle-income country, providing high quality life for all its citizens by the year 2030. This will be through the production of produce goods and services of industrial nature that will be sold beyond her borders to generate real income for the country (Government of Kenya, 2007). It is the technical institutions which are expected to take the drivers seat by mass production of well qualified technologists and engineers. Yet the institutions are not producing people who will take the country to this Promised Land (Kenya National Commission of Human Rights, (KNCHR, 2012). Worse still, the remaining national polytechnics have been takeover of the existing technical institutions by the National Universities such as the Kenya Science Teachers College, Muranga College of Technology and Kenya and Mombasa Polytechniques. This has resulted into the dying of the vocational colleges which fed the manufacturing industries with skilled labour (Cheserek \& Mugalavai, 2012). This begs the question as to the commitment of the government to the achievement of the industrialization goal and the fate of students who are not admitted to the universities (Varghese, 2013).

Failure in the implementation of the reforms in the education sector in general and technical education in particular has been attributed to lack of consultation of the stakeholders and resistance to change among others which are steered by the organization leaders (Obonyo, 2012). Reforms processes in the education sector are largely change management issues under the watch of the institutional leaders. Visionary leadership with innovative approach is a key to make this change happen successfully. Studies by Kaminski (2000), Senge (1999) and Moran and Brightman (2001) revealed that effective change management require constitution of proper organizational structure including the leadership among others. Kessler (2009), Van Sant (2008) and Tropenbos (2007) found out that the product of effective change management should be better problem solving in an institution that leads to improved quality service to customers. It was against the background of the importance of leadership style on the effectiveness of that this study sought to evaluate the change management capacity with regard to the leadership style on the quality of education in the technical institutions in Kenya.

\section{Literature Review}

\subsection{Kotter's Eight-Step Model}

Kotter, one of the most respected experts on the subject of change developed the Eight-Step change management Model.

The first step is to increase urgency for change, which means that management needs to convince employees that this change is necessary for the company to survive (Rose 2011). This also means having to communicate that the change is achievable without any detrimental effects on their jobs.

The next step is to build a team for the change, which has to be of some respected employees in the company. Building an effective team is based on trust and a common goal. When trust is present, you will usually be able to create teamwork (Kotter 1996).

The third step is to construct vision, which will show clear vision as to how the change will better the future of the company and their jobs. In a change process a good vision serves three important purposes; it clarifies the general direction for change and motivates people to take action in the right direction, even if the initial steps are painful. It helps coordinate the actions of different people, even thousands and thousands of individuals, in a remarkably fast and efficient way (Kotter 1996).

The fourth step is to communicate this vision. In order for the vision to work it must be fully understand by the employees, which means that it $\mathrm{s}$ necessary for the leaders of the change group to follow this vision. Nothing undermines the communication of a change vision more than behaviour on the part of key players that seems inconsistent with the vision (Kotter, 1996).

The fifth step is to empower the employees to execute the change. With the right structure, training, systems and supervisors to build on a well-communicated vision, increasing numbers of firms are finding they can tap enormous sources of power to improve organisational performance (Kotter, 1996). 
The sixth step is the creation of short-term goals. By creating short-term goals, we assist the employees to accept the change by showing them progress. Rewards are very important at this stage too.

The seventh step is about persistence because we should influence more change even after the short-term goals are met or the original plan for change will cease and die.

The final step is to make the change permanent by moving and fitting it into the company's culture and practices, such as promotion (Chapman 2006).

The theory was applicable in this study because the researcher had theorized that lack of good leadership leads to erratic implementation of educational reforms (Cheserek and Mugalavai, 2012). The theory also concurred with the views of Tichy (1983) which held that competent policy makers are able to craft visions that earns an organization a competitive advantage. Leaders needed training on teamwork and communication skills to effectively manage change process in their institutions.

\subsection{Leadership Style}

Leadership and its role are the most concerning issue for the business and organizations now days. Leaders are individuals who establish direction for a working group of individuals and who gain commitment from this group of members to established direction and who then motivate members to achieve the direction's outcomes (Conger, 1992). The term leadership can be viewed through multiple angles and concepts. Traditionally leadership is a set of feature owned by the leader or it is a social phenomenon that comes from relationship with groups.

These concepts can give different opinions about the definition of leadership. It is a continuous debate that whether the leadership comes from the personal qualities of a leader or a leader makes followership through what he does or believes (Grint 2004). Grint also highlight position problems with the leadership, which explores, is the leader a person in charge? With the true authority to decide or implement, or it is only a person in front who takes $\mathrm{h} / \mathrm{her}$ directions for someone. Recent reviews take leadership as "a process whereby an individual influences a group of individuals to achieve a common goal (Northouse 2004). Another view about leadership is that "leadership is like the Abominable Snowman, whose footprints are everywhere but who is nowhere to be seen" (Bennis and Nanus 1985).

Dunphy and Stace describe an organization leadership as a person who can promote change in an organization by its vision and strategy (Senior and Fleming 2006). In this era of rapidly changing business trends and increased customer demands, the role of leadership is more crucial now a days. The strategic leadership is eagerly needed for organizations, which is well capable to predict the essential alterations and changes, in advance and create required commitment and highly suitable atmosphere for worker and teams to understand and adopt these changes successfully. This action by leaders is decisive not only for the effectiveness of the organization but also for its very survival (Burke \& Cooper, 2004).

Various leadership styles have been found to influence the change process in the organization. Most notable is the bureaucratic leadership style. Bureaucratic leadership style refers to the following of the predetermined rules and policies of organization (Kellerman, 2003). The leaders are not dynamic and they never change their behavior with the changing environment. Bureaucratic leadership is characterized by leaders that follow the rules precisely and use positional power to influence results. The characteristics of the bureaucratic style include: leaders impose strict and systematic discipline on the followers, and demand business-like conduct in the workplace. They are empowered via the office they hold (position power) and followers are promoted based on their ability to conform to the rules of the office. Subordinates are expected obey leaders because authority is bestowed upon the leader as part of their position in the company (Noer, 1997).

Bureaucratic leader, like authoritarian leader, tells people what to do and how to do. But the bases of all his orders are solely organizational policies, procedures and guidelines. Rules are absolute for bureaucratic leaders. He really works by job description and his job as a manager is more like a judge and he wouldn't accept any exception in rules even in special technical issues. This leader gives people little or no freedom (SeyedJavadin, 2007).

Bureaucratic leaders are also transactional as they impose strict discipline on subordinates and promotions are based on conformity to rules and performance results. Subordinates are expected to follow orders of the leader because of the authority that resides with his position (Kellerman, 2003). This type of leader is only beneficial in hazardous types of jobs where safety is paramount and standards are expected to be followed exactly to ensure accuracy. However, this leadership type may not be applicable in the technical institutions where reforms are being initiated and proper change management process is required. Sorensen and Yukongdi (2010) argued that bureaucracy affected the performance of the employees in an organization because it has significant impact on job satisfaction. 
Participatory leadership plays an important role in growing inner capabilities and priorities the success of the organization (O'Reilly, Caldwell, Chatman, Lapiz and Self, 2010).

Bainbridge (1996) argues that creation and design of change processes within an organization is most often a role of the participatory leaders within it. Change processes are the mandate of leaders engaged in the management of change. It is up to the participatory leaders to make these change initiatives tangible rather than abstract and to awaken enthusiasm and ownership of the proposed changes within the organizations.

For an effective change, the study revealed that charismatic leadership and trust in top management both are important. They are strongly correlated (positively) with change implementing behavior, monitoring of anticipators, management level, and department connection (Michaelis, Stegmaier \& Sonntag, 2009). According to Noer (1997), the leader, as a person, is the most important tool for change. The leader's spirit, insight, wisdom, compassion, values, and learning skills are all important facets in the capabilities to lead others to embrace change and redesign. The leader who prompts change within a firm is often subject to approximate thought (Nadler \& Nadler, 1998). It is the leadership's behavior that makes the change situations more effective (Higgs \& Rowland, 2005).

\subsection{Quality of Education}

Liston (1999) defined quality of education as the total effect of the features of the process, or service on its performance, or the customer's or clients' perception of that performance. It is not just a feature of a finished product or service but involved a focus on internal processes and outputs, and included the reduction of waste and the improvement of productivity. This view of quality applied to education implied that quality cannot be measured by looking at the outputs which are the examination results. Rather it is the internal efficiency of the school system, which controls for wastages in form of school dropouts, repetition rates, or wastage ratios, is a more appropriate measure of the quality of education.

Liston (1999) further argued that quality was related more to the relevance and value of each institution's mission, purpose and objectives and the achievement of identified outcomes. Low capacity of change management in the sector would hamper the achievement of the identified educational objectives. Hoy, Bayne-Jardine and Wood (2000) said that quality was what was good for the school and its students.

Another way of looking at the quality of education is to use the effective schools view which advocates for the black box technique of measuring inputs and outputs (Namaswa, 2009). For a social service like education, this approach cannot be applied in total, as it overlooks certain immeasurable attributes of good education that cannot be read from mere pass rates. Hoy et al. (2000) referred to the 1998 Phi Delta Kappa/Gallup poll of the public's attitudes towards public schools' effectiveness. The percentage of students graduating from high school was rated highest at $82 \%$ while scores of students in standardized tests was ranked lowest at $50 \%$. The public thus viewed quality more to do with the total effect schooling had on the individual rather than just examination results.

According to Ministry of Education (2008) all aspects of the school and its surrounding community, the rights of the whole child, and all children to survival, protection, development and participation are at the centre. This meant that the focus was on learning which strengthened the capacities of children to act progressively on their own through the acquisition of relevant knowledge, useful skills and appropriate attitudes; and which creates for children, and helps them create for themselves and others, places of safety, security and healthy interaction (Bernard, 1999). Many definitions of quality in education exist, testifying to the complexity and multifaceted nature of the concept. The terms efficiency, effectiveness, equity and quality have often been used synonymously (Adams, 1993).

Curriculum has been defined as the foundation of the teaching-learning process that any quality education will depend on its relevance (Sahlberg, 2011). The development of programs of study, learning and teaching resources, lesson plans and assessment of students and even teacher education are all based on relevance of the curriculum (Levin, 2007).

According to De Coninck (2008), curriculum, more than ever before, is now viewed as being at the centre of daily life and the responsibility of society as a whole. Levin (2007) noted that curriculum documents were a very large part of the work done by ministries of education in creating curriculum content. However, over time, the above study stated that educational change is more complex, and as governments have attempted to make large-scale changes, curriculum change has become less of an activity in its own right and curriculum renewal has become part of a broader strategy for change in education to enhance its quality (Sahlberg, 2011).

The reforms in the education sector are aimed at improving the quality of education through improvement of the performance of the students through achievement of better grades. Studies have shown that academic performance which is achievement of good grades remains a crucial factor in determining who graduates from high school and 
who proceeds to college (Perna, 2005; Silver, Saunders \& Zarate, 2008). A number of studies, for example, have found that high school performance and postsecondary educational status is influenced by a student's academic trajectory beginning as early as elementary school which is influenced by the quality of education right from the beginning (Zarate \& Gallimore, 2009).

\section{Methodology}

The study adopted a survey research design to evaluate the management capacity with respect to organizational structure on the quality of technical education in Kenya. According to Mugenda and Mugenda (2003) surveys enable researchers to obtain data about practices, situations or views at one point in time through questionnaires and interviews. It is concerned with the questions as what, how and why of a phenomenon which was the concern for the study (Kothari, 2004). Surveys produce quantitative descriptions of some aspects of the study population of which the study sought to determine the effect of organizational structure on the quality of education.

The target population was all employees in the technical training institutions in Kenya and the management of the Ministry of Educations' Directorate of Technical Education. According to the Directorate's human resource department, there were 31 employees in the job groups $\mathrm{M}$ to $\mathrm{S}$ which is the management cadre. The study targeted all the 47 technical institutes under the TIVET sector in the Ministry of Education, Science and Technology and the Ministry of Labour and Human Resources Development. The study targeted the management and instructors of technical institutions. According to the Directorate of Technical Institutions (2012), there were 4,124 instructors in the public technical institutions in Kenya.

The researcher sampled 14 technical institutions from the total 47 which represented $30 \%$ of the target population which is in line with Mugenda and Mugenda's (2003) recommended 30\% of the population. The researcher then sampled 242 respondents using both stratified random sampling and purposive sampling which is $37 \%$ of the population of the sampled technical institutions. The first strata were the managers of the Directorate of Technical Education. The second strata had the National Polytechnics while the third strata were the other 11 technical institutions.

The research Instruments comprised of structured questionnaires and interview schedules. The questionnaires were preferred as the most suitable instruments for the data collection because they allow researchers reach many respondents (or large samples) within limited time (Mugenda and Mugenda, 2003). The purpose of the interviews was to explore experiences of the management in the change management process. The researcher self-administered the questionnaires to the respondents and conducted interviews with the assistance of trained research assistants.

Data was analysed using both descriptive and inferential statistics with the aid of computer software for data analysis (SPSS). Descriptive statistics consisted of computation of sums, means, standard deviations, frequencies and percentages. Qualitative data was analysed using content analysis. The study used regression analysis to establish how the organizational structure, affected the quality of technical education in Kenya. The model for the regression analysis was:

$\mathrm{Y}=\alpha_{0}+\beta_{1} \mathrm{X}_{1}+\mathrm{e}$

Where:

$\begin{array}{lll}\mathrm{Y} & - & \text { Quality of technical education } \\ \alpha_{0} & - & \text { Is the constant } \\ \mathrm{X}_{1} & - & \text { Leadership style } \\ \beta_{1} & - & \text { Coefficients } \\ \mathrm{e} & - & \text { Error term }\end{array}$

\section{Findings}

\subsection{Leadership Style and Reforms}

To ascertain the kind of leader the principals were, the instructors were asked to describe the principals. The results in Figure 1 show that according to $41.3 \%$ of the instructors the principals were involving. The findings show that $34.3 \%$ of the respondents described the principals as friendly. However, $24.4 \%$ of the respondents described their principals as authoritarian. This meant that most principals were accommodative and approachable except for a few which confirm the views of Hannah, Ball, Lorenzi, Ash, Eindbinder \& McPhee (2005) who in their study noted that the employees perception of the leadership as supportive, concerned and committed to their welfare goes a long way in enhancing change process in the organization. 


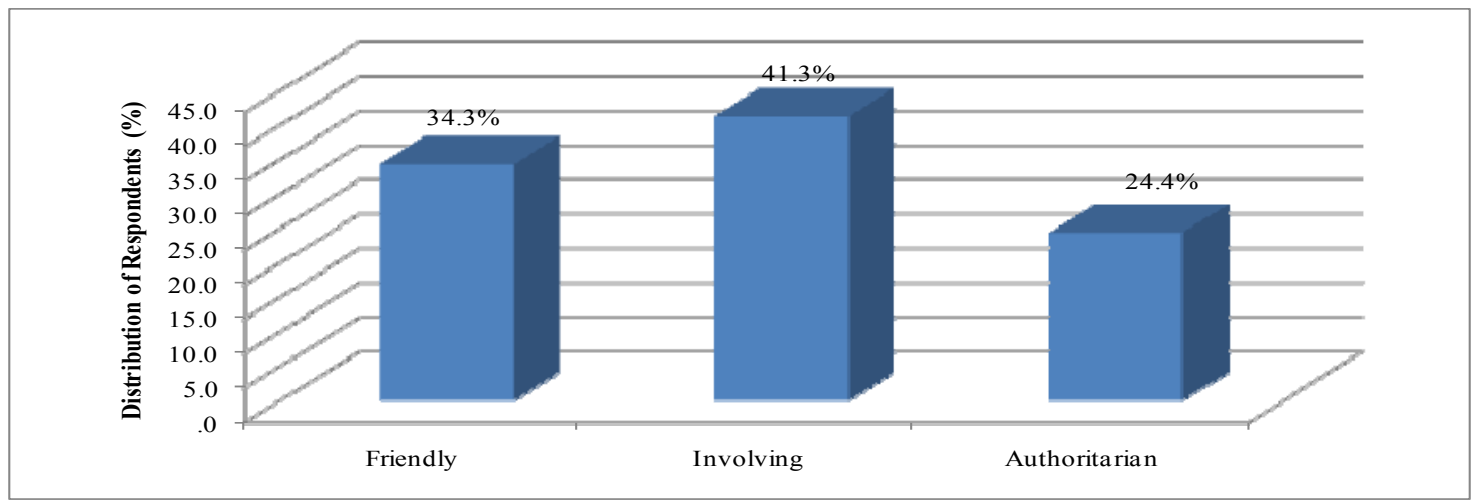

Figure 1. Instructors description of the principal

The study sought to establish from instructors whether the top management was involved in the change processes in the institutions. The results show that majority of the respondents (86\%) indicated that indeed, the top management was involved in the change process in the institutions. Only $12 \%$ had a contrary opinion while two percent did not know. The findings mean that the top management was involved in the change process in the technical educational institutions. The findings therefore confirmed the views of Noer (1997) that the leaders are the most important tool for change.

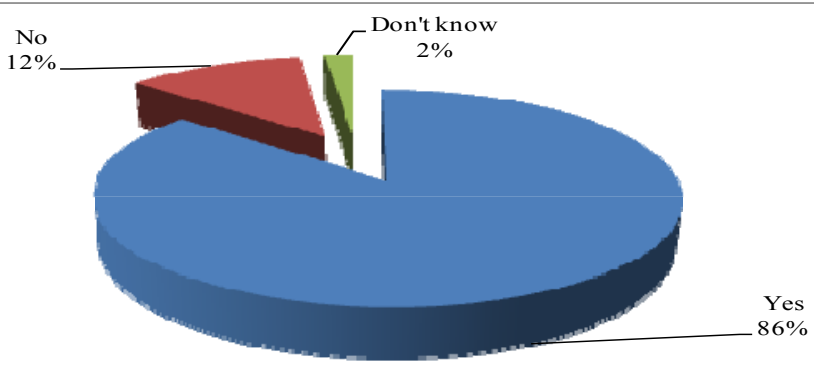

Figure 2. Whether top management was involved in change process

To ascertain the level of involvement of the top management in the implementation of the reforms, the instructors were asked to state the areas of involvement of the top management. The results showed that most of the top management (49.3\%) were involved in the decision making and supervision (30.8\%).

Asked to explain their answers, respondents stated that the management held consultative meetings with various stakeholders on the implementation of the reforms. The respondents also indicated that through restructuring, the top management put up teams which spearheaded the reforms processes in the institutions. They further explained that the management monitored closely how the reform process was progressing demanding regular reports from the implementing teams. These findings meant that the top management of the institutions were providing leadership in the implementation of the reforms as recommended by Bainbridge (1996) who argued that the creation and design of change processes within an organization is most often a role of the leaders within it.

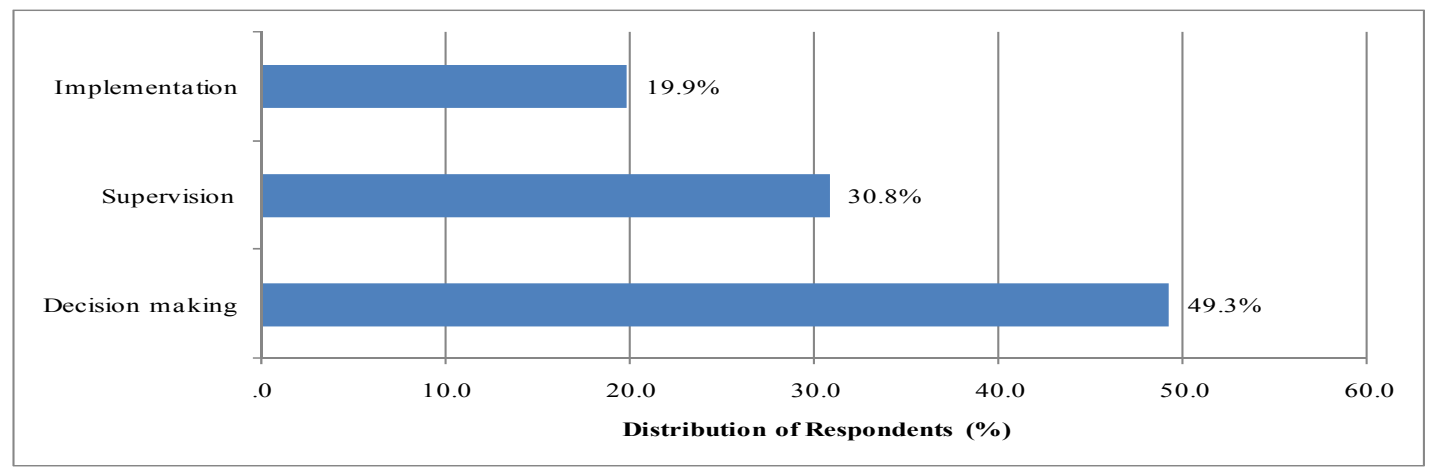

Figure 3. Areas of involvement in implementation of reforms by top management 
The instructors were asked to state the extent to which the leadership provided them with support in their assignments to ascertain whether there was a team effort in the change process as advocated by Kotter (2007) that leadership is a team effort of a variety of individual input. The results in Figure 4 showed that most of the instructors $(42.8 \%)$ indicated that the leadership supported them in their assignments to a large extent while $12.9 \%$ of the respondents stated that they were assisted in their assignments. The findings meant that in most of the technical educational institutions, the leadership encouraged teamwork in the change process.

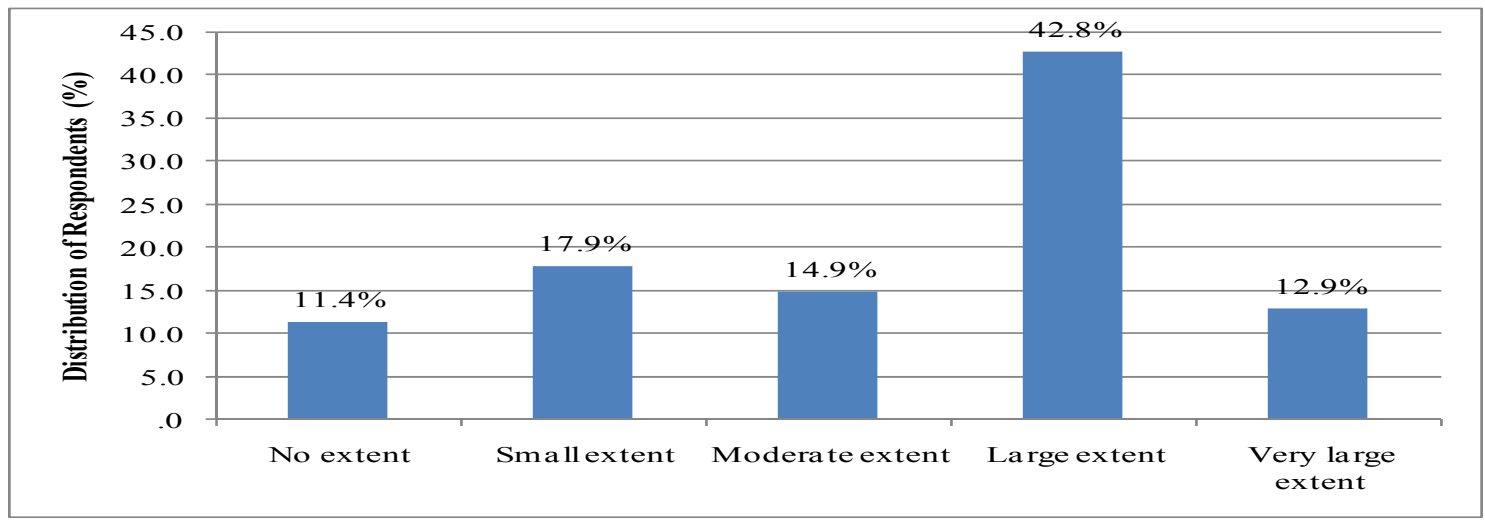

Figure 4. Extent leadership provide support to its staff

The instructors were asked to state the extent to which the institution leadership took lead of the change process. The findings in Figure 5 showed that most of the instructors (44.3\%) stated that the leadership took lead of the change process to a large extent. The findings also showed that $24.4 \%$ of the respondents indicated that the leadership tool lead to a very large extent. The results therefore meant that the leadership of the institutions was in the front line of the change process in the institutions which are in support of the views by Bainbridge (1996) view that the leadership should take leadership by designing change process within the organization.

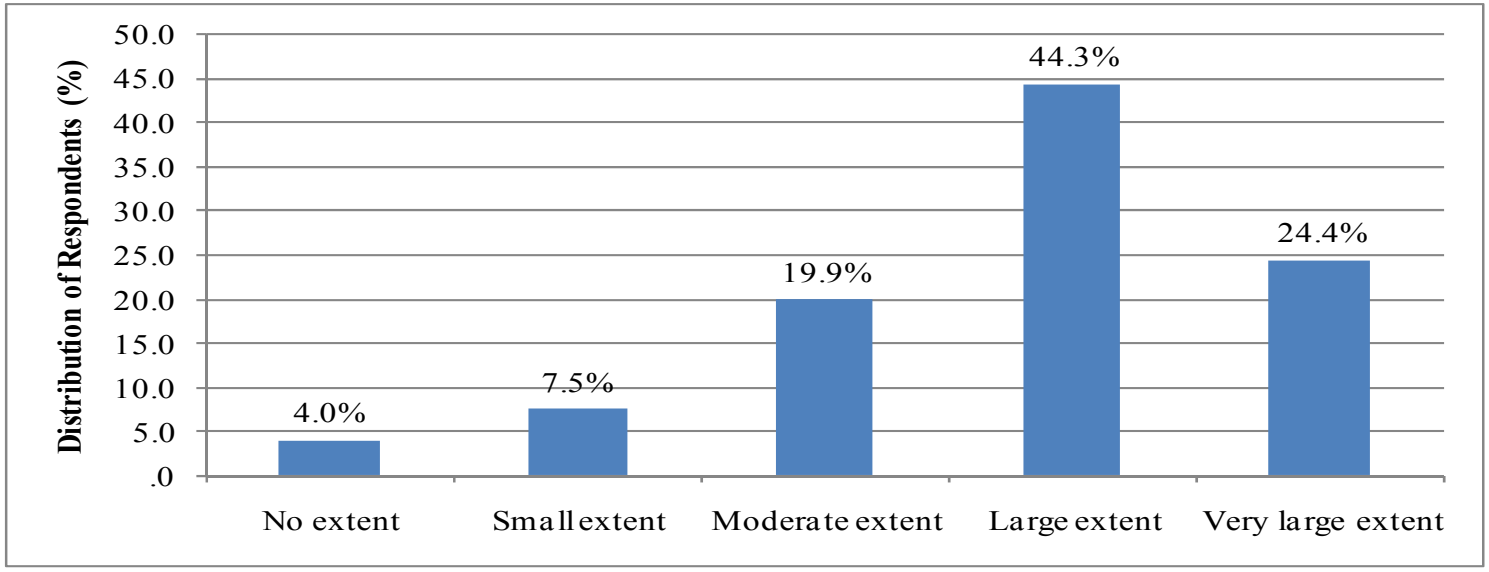

Figure 5. Whether leadership takes lead in the change process

The instructors were asked to state the level of agreement with the influence of leadership style on the change process in the technical educational institutions. This was on the scale of strongly disagree, disagree, neutral, agree and strongly agree. The factors rated included principals' involvement, adherence to rules, principals giving instructions and freedom to staff. The findings in Table 1 show that $33.3 \%$ of the respondents agreed that the principals' were involved in the staff in decision making while the $38.3 \%$ of the respondents strongly agreed that the principals involved staff in decision making. The mean score value of 3.97 implied that generally the principals involved the other staff in decision making. There were variances in the responses (standard deviation $\geq 1$ ).

As to whether the rules were followed strictly in the process of change, the findings show that $37.8 \%$ of the respondents agreed that the rules were followed strictly while $16.4 \%$ strongly agreed that the rules were strictly followed. The mean score of 3.47 meant that the respondents generally agreed that the rules were strictly followed. There were variances in the responses (standard deviation $\geq 1$ ). 
On whether the principal gave orders on what or did not involve staff in the process or left the process to take its course, the findings show that most of the respondents (44.8\%) disagreed with the statement that the principal does not involve staff but leave process to take course. The findings show that $22.9 \%$ of the respondents agreed that the principal does not involve staff but leave process to take course. The mean score of 2.47 mean that the respondents did not agree with the statement which implied that the principals gave direction of what needs to take place. There were variances in the responses (standard deviation $\geq 1$ ).

As to whether the principal gave orders on what was to be done at every stage of change process, the findings show that most of the respondents $(47.3 \%)$ remained neutral. However, $24.4 \%$ of the respondents strongly agreed that the principals give orders on what to be done at every stage of change process. The mean score of 3.52 meant that generally the respondents agreed that the principals gave orders on what to be done at every stage of the change process. The findings therefore mean that the principals were in charge of the change process. There were variances in the responses (standard deviation $\geq 1$ ).

Table 1. Leadership and management

\begin{tabular}{|c|c|c|c|c|c|c|c|}
\hline & $\begin{array}{l}\text { Strongly } \\
\text { disagree } \\
(\%)\end{array}$ & $\begin{array}{l}\text { Disagree } \\
(\%)\end{array}$ & $\begin{array}{l}\text { Neutral } \\
(\%)\end{array}$ & $\begin{array}{l}\text { Agree } \\
(\%)\end{array}$ & $\begin{array}{l}\text { Strongly } \\
\text { agree }(\%)\end{array}$ & Mean & $\begin{array}{l}\text { Std. } \\
\text { Dev }\end{array}$ \\
\hline $\begin{array}{l}\text { Principals involve staff in } \\
\text { decision making }\end{array}$ & .0 & 12.9 & 15.4 & 33.3 & 38.3 & 3.97 & 1.029 \\
\hline $\begin{array}{l}\text { Rules followed strictly in } \\
\text { the process }\end{array}$ & 2.0 & 19.9 & 23.9 & 37.8 & 16.4 & 3.47 & 1.049 \\
\hline $\begin{array}{l}\text { Principal does not involve } \\
\text { staff but leave process to } \\
\text { take course }\end{array}$ & 19.4 & 44.8 & 9.0 & 22.9 & 4.0 & 2.47 & 1.158 \\
\hline $\begin{array}{l}\text { Principal gives orders on } \\
\text { what is to be done at every } \\
\text { stage of change process }\end{array}$ & 2.0 & 8.5 & 47.3 & 17.9 & 24.4 & 3.52 & 1.006 \\
\hline $\begin{array}{l}\text { Staff is free to do what they } \\
\text { think is right }\end{array}$ & 20.4 & 43.3 & 5.5 & 19.4 & 11.4 & 2.59 & 1.325 \\
\hline Average & 8.8 & 25.9 & 20.2 & 26.3 & 18.9 & & \\
\hline
\end{tabular}

The study sought to determine from the instructors the extent to which the leadership had influenced the quality of education in the technical educational institutions. The findings in Figure 6 show that most of the respondents $(44.8 \%)$ indicated that the leadership style to a large extent influenced the implementation of change in the institutions which in turn enhanced the quality of education in the institution. The result further show that $26.7 \%$ of the respondents indicated that leadership style to a very large extent influenced the implementation of change and hence the quality of education in the technical education institutions.

When asked to explain how the leadership had influenced the implementation of changes in the institutions, the respondents stated that the kind of leadership determined whether the employees would corporate during the implementation of the reforms. Three respondents also indicated that the leader who is in charge of the process will ensure that the reforms are implemented effectively thereby enhancing the quality of education in the institutions. Two instructors indicated that where the leader consulted with other staff or the leadership was inclusive, there was a collective responsibility in the change process and therefore enhanced the quality of education. The respondents further explained that the leadership style of the principal had negatively influenced the quality of education in the institutions as the employees had become resistant to the reforms and therefore the process of change in most cases did not succeed which in turn have led to the low quality of education. From these findings of the study, it became evident that the leadership style of the principals of the technical educational institutions in Kenya influenced the quality of education as they determined the success of the change process or its failure as argued by Bainbridge (1996) that the creation and design the success of change processes within an organization is most often a role of the leaders within it. 


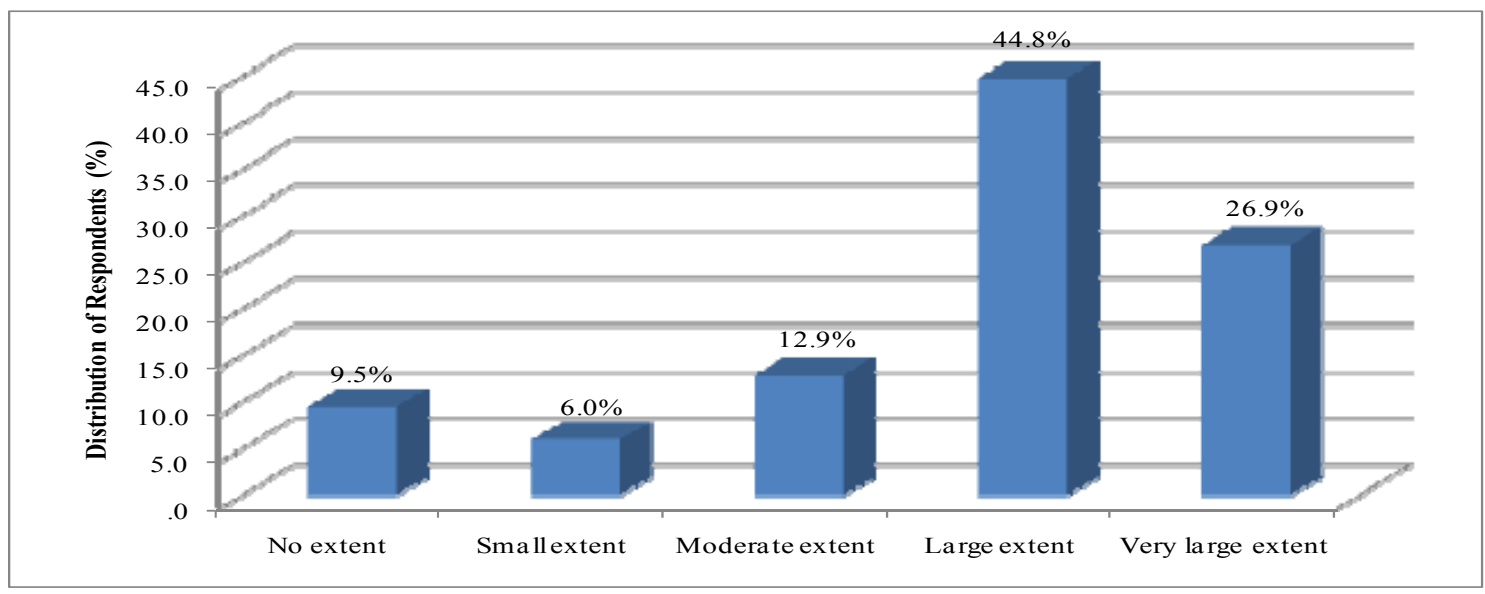

Figure 6. Extent leadership has influenced quality of education

\subsection{Quality of Technical Education}

The study sought to determine the quality of technical education. The institutional managers were therefore asked to state their level of agreement with the statements regarding the quality of technical education in their institutions. The study findings on table 2 showed that most of the institutional managers $(45.5 \%)$ disagreed that the institutions produced competent graduates fit for the job market while $18.8 \%$ of them strongly agreed with this statement. The results show that on average, the institutional managers (45.5\%) were neutral as to whether the graduates were competent and fit into the market or not (mean score, 2.82). The study findings show that most of the institutional managers $(27.3 \%)$ disagreed that the graduates got absorbed into the job markets. This was confirmed by the mean score (2.45). The findings of the study also show that most of the institutional managers (36.4\%) neither agreed nor disagreed with the statement that the number of enrolment in their institutions have been going up. $36.4 \%$ of the respondents agreed that there has been minimal drop out of students while $18.2 \%$ strongly agreed that there was minimal dropout of students. The findings showed that generally, the respondents agreed that the dropout of students was minimal. There were variances in the responses (standard deviation $\geq 1$ ). The respondents explained that despite the success in producing many graduates into the job market, the employers had always complained that the graduates are half baked. The respondents also explained that the time allocated for attachment was too short for the graduates to integrate with the practical work.

Table 2. Quality of technical education

\begin{tabular}{|c|c|c|c|c|c|c|c|}
\hline & $\begin{array}{l}\text { Strongly } \\
\text { disagree } \\
(\%)\end{array}$ & $\begin{array}{l}\text { Disagree } \\
(\%)\end{array}$ & $\begin{array}{l}\text { Neither } \\
\text { agree nor } \\
\text { disagree } \\
(\%)\end{array}$ & $\begin{array}{l}\text { Agree } \\
(\%)\end{array}$ & $\begin{array}{l}\text { Strongly } \\
\text { agree }(\%)\end{array}$ & Mean & $\begin{array}{l}\text { Std. } \\
\text { Dev }\end{array}$ \\
\hline $\begin{array}{l}\text { Institution produces } \\
\text { competent graduates fit for } \\
\text { the job market }\end{array}$ & 9.1 & 45.5 & 18.2 & 18.2 & 9.1 & 2.82 & .751 \\
\hline $\begin{array}{l}\text { Graduates get absorbed into } \\
\text { the job market }\end{array}$ & 9.1 & 27.3 & 45.5 & 18.2 & .0 & 2.45 & .522 \\
\hline $\begin{array}{l}\text { The number of enrolment } \\
\text { has been going up }\end{array}$ & 9.1 & 18.2 & 36.4 & 27.3 & 9.1 & 2.27 & .647 \\
\hline $\begin{array}{l}\text { There is minimal drop out } \\
\text { of students }\end{array}$ & 9.1 & 9.1 & 27.3 & 36.4 & 18.2 & 3.55 & .688 \\
\hline
\end{tabular}

\subsection{Correlation Analysis}

The study conducted correlation analysis to test the strength of association/relationship between the research variables. Correlation is the measure of the relationship or association between two continuous numeric variables. Correlation analysis results give a correlation coefficient which measures the linear association between two variables (Crossman, 2013). The results in Table 3 showed that the leadership style is positively related to quality of education with a Pearson Correlation Coefficient of 0.018 and a level of significance of 0.035 hence statistically significant as the p-value is less than 0.05 . This relationship was however weak. 
Table 3. Correlation

\begin{tabular}{llcc}
\hline & & Leadership style & Quality of education \\
\hline Leadership style & Pearson Correlation & 1 & .018 \\
& Sig. (2-tailed) & & .035 \\
Quality of education & Pearson Correlation & .018 & 1 \\
& Sig. (2-tailed) & .035 & \\
\hline
\end{tabular}

\subsection{Regression Analysis}

The study further carried out regression analysis to establish the statistical significance relationship between the independent variable, leadership style and the dependent variable, quality of technical education. According to Green and Salkind (2003) regression analysis is a statistics process of estimating the relationship between variables. It helps in generating equation that describes the statistical relationship between one or more predictor variables and the response variable. The regression analysis results were presented using regression model summary tables, analysis of variance (ANOVA) table and beta coefficient tables.

Regression analysis was further conducted to determine the relationship between the leadership style and the quality of education. Table 4 showed that the coefficient of determination is 0.64 therefore; about $64.0 \%$ of the variation in the quality of technical education is explained by the leadership style. This implied that there existed a strong positive relationship between the leadership style and the quality of education in technical educational institutions.

Table 4. Regression model summary

\begin{tabular}{lcccc}
\hline Model & $\mathrm{R}$ & $\mathrm{R}$ Square & Adjusted R Square & Std. Error of the Estimate \\
\hline 1 & $.800^{\mathrm{a}}$ & .640 & .591 & .208 \\
\hline
\end{tabular}

The ANOVA results for regression coefficients in Table 5 showed that the significance of the $\mathrm{F}$ statistics is 0.000 which is less than 0.05 . This implied that the independent variable (leadership style) explained the variation in the dependent variable (quality of education). Therefore the model was significant.

Table 5. ANOVA

\begin{tabular}{llrrrrr}
\hline Model & & Sum of Squares & df & Mean Square & F & \multicolumn{1}{c}{ Sig. } \\
\hline 1 & Regression & 1.576 & 1 & 1.576 & 2.819 & $.095^{\mathrm{a}}$ \\
& Residual & 11.260 & 199 & .559 & & \\
& Total & 112.836 & 200 & & & \\
\hline
\end{tabular}

The beta coefficients of leadership style verses the quality of education in technical educational institutions results in Table 6 showed that there was significant relationship between the leadership styles and the quality of education was positive since the coefficient of organizational structure is 0.109 which is significantly greater than zero. The $t$ statistics (1.679) was also greater than zero. This demonstrated that the leadership style had a positive influence on the quality education in technical educational institutions.

Table 6. Coefficients

\begin{tabular}{|c|c|c|c|c|c|c|}
\hline \multirow{2}{*}{\multicolumn{2}{|c|}{ Model }} & \multicolumn{2}{|c|}{ Unstandardized Coefficients } & $\begin{array}{l}\text { Standardized } \\
\text { Coefficients }\end{array}$ & \multirow[b]{2}{*}{$\mathrm{t}$} & \multirow[b]{2}{*}{ Sig. } \\
\hline & & $\mathrm{B}$ & Std. Error & Beta & & \\
\hline \multirow[t]{2}{*}{1} & (Constant) & 1.507 & .135 & & 11.136 & .000 \\
\hline & Leadership & 109 & .065 & .118 & 1.679 & .095 \\
\hline
\end{tabular}

\section{Hypothesis}

The hypothesis was tested using the Chi Square test where the researcher sought to determine whether there was any relationship between the leadership style and the quality of technical education represented as:

Ho: Leadership style has no significant influence on the quality of technical educational institutions in Kenya.

The results are presented on Table 7.

Table 7. Chi Square Test for leadership

\begin{tabular}{lr}
\hline & Leadership \\
\hline Chi-Square & $74.881^{\mathrm{a}}$ \\
df & 3 \\
Asymp. Sig. & .000 \\
\hline
\end{tabular}


Since $p$-value $=0.000 \leq 0.05$, the null hypothesis was rejected. The study therefore concludes that the leadership style significantly influenced the quality of technical educational institutions.

\section{Discussion}

The factor analysis result on leadership style was 0.733 and the loading results were between 0.980 and 0.291 . Using the leadership style indicators, the value of the Cronbach's Alpha was computed again and generated a value of 0.737. The study therefore deduced that eight out of eleven indicators of leadership style were reliable in assessing the effect of organizational structure in determining the success of reforms in technical educational institutions and hence the quality of technical education.

Descriptive results revealed that the leadership in the institutions was mostly described as involving by most of the instructors $(41.3 \%)$. The findings also show that $34.3 \%$ of the instructors described the leadership as friendly. These findings confirmed the opinions Hannah et al (2005) that the employee perception of leadership concerning their welfare is important in enhancing change process in the organization.

The study established that according to majority of the respondents (86\%) the top management was involved in the change process. The area of involvement was in decision making (49.3\%). The study established that according to majority of the respondents (68.7\%) indicated that the leadership in the institutions took the lead in the change process. These findings supported the views by O'Reilly et al (2010) that participatory leadership plays an important role in growing inner capabilities and priorities for the success of the organization.

The study results revealed that according to most respondents (mean score 3.47) the management strictly followed in the rules of the change process. The principals also gave orders on what is to be done at every stage of the change process according to most of the respondents (mean score 3.52). These findings agreed with Bainbridge (1996) that change process in the organization is the mandate of leaders engaged in the management of change. He argued that it is the responsibility of the leader to make the change initiative tangible.

The findings also revealed that majority of the instructors (71.4\%) indicated that the leadership influenced the quality of technical education through supervision and provision of direction. These results support the views of Higgs and Rowland (2005) who noted that the leadership behaviour was very important in making the change situation more effective in the organization.

The Pearson Correlation analysis of leadership style results gave a correlation of 0.112 which demonstrated that leadership style had a positive correlation with the quality of education. Regression model of leadership skills versus the quality of technical education gave a coefficient of determination of R square of 0.640 at 0.05 significant level. The coefficient of determination indicates that $64 \%$ of the response of quality of education was explained by leadership style of the organization. This implied that there existed a strong relationship between leadership style and the quality of technical education in technical educational institutions in Kenya. The findings of the relationship between the leadership style and quality of technical education supported the views by Michaelis, et al (2009) that the effective change is strongly correlated (positive) with change implementing behaviour, monitoring of change process.

The study established that most of the institutional managers (45.5\%) disagreed that the institutions produced competent graduates fit for the job market. The findings also revealed that $18.8 \%$ of the respondents agreed that institutions produced competent graduates fit for the job market. The findings showed that most of the respondents were non committal as to whether the graduates got absorbed into the job markets (mean score 2.45). The findings of the study show that $27.3 \%$ of the respondents either agreed or strongly agreed that the number of enrolment in their institutions had been going up. However, it can be said that generally, respondents strongly agreed that there has been increase in the number of enrolments in the institutions (mean score, 4.27). The results showed that $36.4 \%$ of the respondents agreed that there had been minimal drop out of students while $18.2 \%$ strongly agreed that there was minimal dropout of students. The findings that the graduates are able to be absorbed into the job market supported the views of Perna (2005) and Silver, Saunders and Zarate (2008) that quality education is achieved when the students are able to graduate, and proceed to the next level. The aim of the technical institutions is to prepare the students to enter the job market.

The regression model of quality of education coefficient of determination R Square was 0.711 and $\mathrm{R}$ was 0.843 at 0.05 significant level. The coefficient of determination indicated that $71.1 \%$ of the variation in quality of education could be explained by organizational structure, leadership style and policy makers competence. The remaining $28.9 \%$ of the quality of technical education was explained by variable which were not included in the model. 


\section{Summary}

According to $41.3 \%$ of instructors the leadership in the institutions as involving and friendly. It was established that $86 \%$ of the instructors stated the top management was involved in the change process where they took lead in the change process through decision making (49.3\%) as was advocated by O'Reilly et al (2010) that participatory leadership plays an important role in growing inner capabilities and priorities for the success of the organization. The study results revealed that the principals gave orders on what was to be done at every stage of the change process (mean score 3.52). It was further revealed that majority of the instructors $(71.4 \%)$ indicated that flexible leadership style positively influenced the quality of technical education through supervision and provision of direction.

The study established that most of the institutional managers stated that the institutions did not produce competent graduates fit for the job market. The findings showed that most of the respondents did not agreed that the graduates got absorbed into the job markets (mean score 2.45). The findings of the study show that $27.3 \%$ of the respondents either agreed or strongly agreed that the number of enrolment in their institutions had been rising. Most of the respondents stated that there has been minimal drop out of students.

\section{Conclusion}

The leadership style influenced the success of the reforms process in the organizations as the process became more successful where the management involved other staff in the process but took the leadership role which will in turn enhanced the quality of the technical education.

\section{Recommendations}

The management of the technical educational institutions should adopt leadership styles which could accommodate the views of every staff and involved everyone in the process but the management should show that way of reforms or change.

\section{References}

Gachukia, E. (2007). Affordable Secondary Education. Task Force Report, Nairobi.

Government of Kenya, (GOK). (2005). Sessional Paper No.1 on Policy Framework for Education, Training and Research. Nairobi; Government Printer.

Gunter, H. (2008). Policy and workforce reforms in England. Educational Management Administrational Leadership, 36, 253-270. http://dx.doi.org/10.1177/1741143207087776

Hargreaves, A. (2005). Educational change takes ages: life career and generational factors in teachers' emotional responses to educational change. Teaching and Teacher Education, 21(8), 967-983. http://dx.doi.org/10.1016/j.tate.2005.06.007

Harris, A. (2009). Big change question: does politics help or hinder education change? Journal of Educational Change, 10, 63-67. http://dx.doi.org/10.1007/s10833-008-9093-7

Harris, A. (2011). Reforming systems: Realizing the fourth way. Journal of Educational Change, 12(2), 159-171. http://dx.doi.org/10.1007/s10833-011-9156-z

Jamila, R. (2012). The management of educational change in Pakistani Educational Institutions. Thesis for University of Glasgow.

Kellerman, R. (2003). The Leadership Style and its Relation with Employee Attitudes and Behavior. SA Journal of Industrial Psycology, 29(2), 72-82.

Kennedy, K., \& Lee, J.C.K. (2008). The Changing Role of Schools in Asian Societies-Schools for the Knowledge Society. London: Routledge.

Levin, B. (2007). Curriculum for the 21st century: Does curriculum matter? Education Services Australia. Retrieved November 25, 2013, from http://www.eqa.edu.au/site/doescurriculummatter.html

Levin, B. (2009). Does politics help or hinder education change? Journal of Educational Change, 10, 69-72. http://dx.doi.org/10.1007/s10833-008-9092-8

Levin, B. (2010). Governments and education reforms: some lessons from the last 50 years. Journal of Education Policy, 25(6), 736-747. http://dx.doi.org/10.1080/02680939.2010.523793

Levin, B., \& Fullan, M. (2008). Learning about system renewal. Educational Management Administration Leadership, 36(2), 289-303. http://dx.doi.org/10.1177/1741143207087778 
Michaelis, B., Stegmaier, R., \& Sonntag, R. (2009). Affective Commitment to Change and Innovation Implementation Behavior: The Role of Charismatic Leadership and Employees' Trust in Top Management. Journal of Change Management, 9(4), 399-417. http://dx.doi.org/10.1080/14697010903360608

Mugenda, O.M., \& Mugenda, A.G. (2003). Research Methods, Quantitative and Qualitative Approaches. Nairobi, Kenya. ACT S Press.

Noer, D. M. (1997). Breaking free: A prescription for personal and organizational change. San Francisco: Jossey-Bass.

O'Reilly, C. A., Caldwell, D. F., Chatman, J. A., Lapiz, M., \& Self, W. (2010). How leadership matters: The effects of leaders' alignment on strategy implementation. The Leadership Quarterly 21(2010), 104-113. http://dx.doi.org/10.1016/j.leaqua.2009.10.008

Ojiambo, O. C. P. (2009). Quality of Education and Its Roles in National Development: A Case Study of Kenya's Educational Reforms. Kenya Studies Review, 1(1), 133-149.

Owate, W.O. (2012). Highlights of the Technical and Vocational Education and Training Bill, 2012. Presented at the workshop on Education, Training and Research Policy, Science, Technology and Innovation Policy and Legal Frameworks for Members of Parliament.

Senge, P. et al. (2008). The necessary revolution - How individuals and organizations are working together to create a sustainable world. New York: Doubleday.

SeyedJavadin, R., \& Yazdani, S. (2007). Factors Affecting the Intention of Customers in Using Online.

Yukongdi, V. (2010). A study of Thai Employees preferred Leadership Style. Asian Pacific Business Review, 16, 161-181. http://dx.doi.org/10.1080/13602380903168962 